\title{
FITOPLANKTON SEBAGAI BIOINDIKATOR SAPROBITAS PERAIRAN DI SITU BULAKAN KOTA TANGERANG
}

\author{
Sinta Ramadhania Putri Maresi, Priyanti, Etyn Yunita* \\ Program Studi Biologi, Fakultas Sains dan Teknologi, Universitas Islam Negeri Syarif Hidayatullah Jakarta
}

*Corresponding author: etyn@uinjkt.ac.id

\begin{abstract}
Industry, homes activites, and aquaculture around situ or lake could contaminate and affect the water quality. This study aimed to determine the diversity of phytoplankton and water pollution level in Situ Bulakan Kota Tangerang based on saprobite index. The research was conducted on December 2014 until March 2015 at Situ Bulakan Kota Tangerang. Observations were made based on 4 points sampling with three repetitions for one day that could represented existing condition. Sampling sites in this study were at inlet flow, middle, outlet, and alleged utilized areas such as floating fish net. The result showed 26 species of phytoplankton from four classes, namely 9 species of Cyanophyceae, 4 species of Bacillariophyceae, 11 species of Chlorophyceae, and 2 species of Euglenophyceae with moderate diversity index $\left(H^{\prime}=1.77-2.05\right)$. Monoraphidium sp. was a species dominated in Situ Bulakan Kota Tangerang which was found 215 individuals. So it can be said as saprobite bioindicator. Saprobite index in Situ Bulakan Kota Tangerang showed moderate to severe contaminated with $\alpha$-mesosaprobic (0.14).
\end{abstract}

Keywords : Situ Bulakan, pollution, phytoplankton, bioindicator, saprobite

\section{PENDAHULUAN}

Situ atau danau merupakan salah satu ekosistem air tawar yang sifat airnya tenang (lentik), terakumulasi dalam suatu tempat, dan keberadaan tumbuhan air terbatas hanya pada daerah pinggir saja (Barus, 2004). Kota Tangerang memiliki 6 buah situ sebagai daerah resapan air dan sumber air permukaan, yaitu Situ Cipondoh (126,17 Ha), Situ Bulakan (15 Ha), Situ Cangkring (6,17 Ha), Situ Gede (5,07 Ha), Situ Bojong (0,6 Ha), dan Situ Kunciran (0,3 Ha) (BPLH Kota Tangerang, 2013).

Situ Kunciran dan Situ Bojong merupakan 2 buah situ di Kota Tangerang yang selama ini terinventarisasi ke dalam data Dinas Pekerjaan Umum, namun kondisi di lapangan tidak ditemukan perairan lagi akibat perubahan fungsi situ menjadi daratan. Selain itu, perubahan alih fungsi situ menjadi daratan juga terjadi di Situ Bulakan Kota Tangerang yang awalnya memiliki luas sekitar $30 \mathrm{Ha}$ menjadi 15 Ha. Perubahan fungsi situ menjadi daratan di Kota Tangerang seharusnya perlu dihindari dan dilakukan pemantauan kualitas perairan agar fungsi situ yang awalnya menjadi daerah resapan dan sumber air permukaan tetap terjaga.

Salah satu cara untuk pemantauan kualitas perairan dapat dilakukan penelitian secara biologi menggunakan indikator fitoplankton. Fitoplankton dijadikan sebagai indikator kualitas perairan karena siklus hidupnya pendek, respon yang sangat cepat terhadap perubahan lingkungan (Nugroho, 2006), dan merupakan produsen primer yang menghasilkan bahan organik serta oksigen yang bermanfaat bagi kehidupan perairan dengan cara fotosintesis (Nybakken, 1992). Pengaruh cahaya matahari dalam proses fotosintesis juga menyebabkan fitoplankton berdistribusi secara horizontal (Arinardi et al., 1997).

Fitoplankton yang dijadikan sebagai indikator kualitas perairan berhubungan dengan indeks saprobitas perairan. Indeks saprobitas perairan diukur menggunakan jenis fitoplankton yang ditemukan, karena setiap jenis fitoplankton merupakan penyusun dari kelompok saprobik tertentu yang akan mempengaruhi nilai saprobitas (Indrayani et al., 2014). 
Situ Bulakan sebagai situ terbesar kedua di Kota Tangerang dengan luas 15 Ha merupakan tempat penampungan air yang digunakan untuk mengendalikan banjir. Berdasarkan hasil survei pendahuluan, terlihat bahwa Situ Bulakan Kota Tangerang dimanfaatkan sebagai sarana rekreasi yang banyak didatangi pengunjung, selain itu banyak terdapat rumah makan yang berada di sepanjang badan perairan. Situ Bulakan Kota Tangerang juga memiliki sistem perairan terbuka sehingga menyebabkan air yang masuk lebih banyak berasal dari limbah domestik perumahan, industri, dan air hujan. Kegiatan budidaya perikanan dengan teknik keramba jaring apung juga ditemukan di sekitar perairan Situ Bulakan dengan ikan budidaya seperti ikan mujair (Oreochromis mossambicus), ikan nila (Oreochromis niloticus) dan ikan gabus (Ophiocephalus striatus). Kondisi tersebut sangat memungkinkan situ tersebut tercemar oleh bahan-bahan pencemar (Marganof, 2007).

Sampai saat ini, pemantauan kondisi kualitas perairan dan informasi mengenai keanekaragaman fitoplankton yang digunakan sebagai bioindikator kualitas dan pencemaran perairan di Situ Bulakan Kota Tangerang belum dilakukan. Oleh karena itu, fokus penelitian di Situ Bulakan Kota Tangerang sebagai situ terbesar kedua setelah Situ Cipondoh perlu dilakukan untuk menghindari perubahan alih fungsi situ dan sebagai upaya penyediaan data awal kondisi kawasan Situ Bulakan Kota Tangerang untuk kegiatan monitoring secara berkala. Tujuan penelitian ini adalah mengetahui keanekaragaman fitoplankton dan kondisi saprobitas perairan di Situ Bulakan Kota Tangerang berdasarkan indikator fitoplankton.

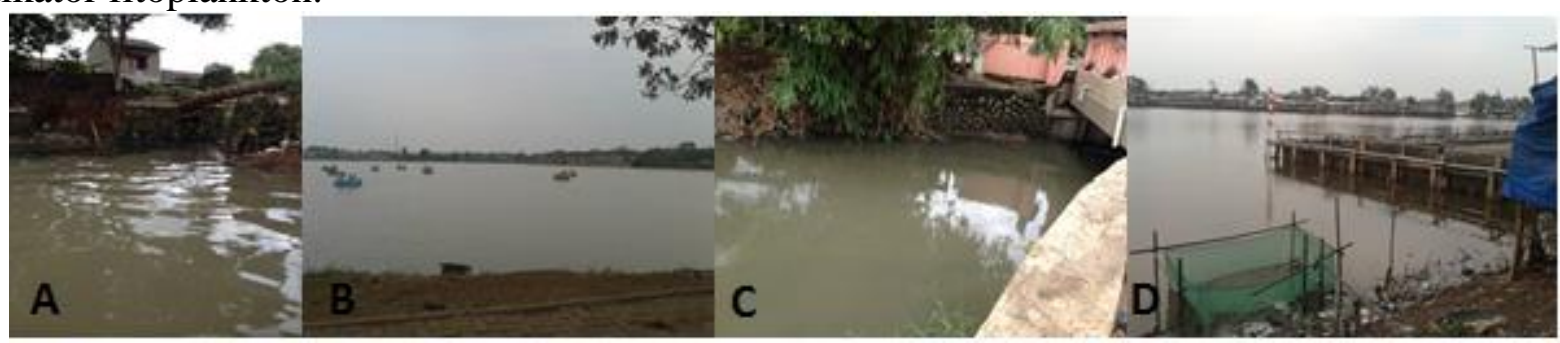

\section{MATERIAL DAN METODE}

Penelitian ini dilakukan pada bulan Desember 2014 hingga Maret 2015 dengan pengambilan sampel pada tanggal 14 Januari 2015 di Situ Bulakan Kota Tangerang, Kecamatan Periuk, Kota Tangerang, Provinsi Banten. Analisis air dan identifikasi fitoplankton dilakukan di Laboratorium Biologi Pusat Sarana Pengen-dalian Dampak Lingkungan (Pusar-pedal) Ke-menterian Lingkungan Hidup.

Bahan yang digunakan dalam penelitian ini adalah sampel air yang diambil dari Situ Bulakan, lugol 1\%, aquades, dan kit amoniak $\left(\mathrm{NH}_{3}-\mathrm{N}\right)$. Alat yang digunakan dalam penelitian ini adalah mikroskop cahaya (Olympus BH2-RFCA), spektrofotometer UV-Vis (InScienPro US-120), digital depth sounder (Hondex PS-Z), conductivity meter (Hach sesion5), $\mathrm{pH}$ meter (Horiba D-51), GPS (Garmin), secchi disc, plankton net no. 25, sedgwick rafter counting cell dengan ukuran panjang $50 \mathrm{~mm}$, lebar $20 \mathrm{~mm}$, dan tinggi 1 $\mathrm{mm}$ (memiliki volume $1000 \mathrm{~mm}^{3}$ ), gelas ukur, pipet tetes, gelas objek, botol sampel polyethilen ukuran $30 \mathrm{ml}$, kertas saring, kamera digital, counter, dan buku identifikasi fitoplankton.

Penentuan titik pengambilan sampel ditetapkan sebanyak 4 stasiun (aliran inlet, bagian tengah, outlet, dan keramba) yang dianggap mewakili beberapa kondisi yang ada. Teknik sampling dilakukan secara acak pada masing-masing stasiun penelitian dan pencuplikan dilakukan 3 kali pengulangan. Pengambilan sampel air untuk identifikasi fitoplankton dilakukan pada satu hari pengamatan yaitu pukul 08.00 - 10.00 WIB.

Gambar 1. Stasiun penelitian di Situ Bulakan Kota Tangerang; A. Aliran inlet; B. Bagian tengah; C. Aliran outlet; D. Keramba 
Sampel air untuk identifikasi fitoplankton diambil di permukaan air secara horizontal dengan kedalaman 0,5 m menggunakan plankton net no. 25 yang dilemparkan sejauh $3 \mathrm{~m}$ ke perairan, lalu bagian talinya ditarik sehingga didapatkan sampel air yang dipekatkan. Sampel air yang didapatkan dari masing-masing stasiun penelitian dengan 3 kali pengulangan diambil sebanyak $27 \mathrm{ml}$ dan dimasukkan ke dalam botol sampel ukuran $30 \mathrm{ml}$ yang telah berisi $3 \mathrm{ml}$ lugol 1\% dan diberi label. Metode pengambilan contoh uji air permukaan sesuai dengan SNI No. 6989.572008 .

Sampel air dalam botol sampel diambil menggunakan pipet, kemudian diteteskan ke dalam bilik pencacah sedgwick rafter counting cell kapasitas 1 $\mathrm{ml}$ dan ditutup menggunakan gelas objek. Pengamatan fitoplankton dalam sedgwick rafter counting cell dilakukan sebanyak 3 kali pengulangan di bawah mikroskop cahaya dengan perbesaran $10 \times 10$. Proses pencacahan dilakukan dengan bantuan alat hitung counter.

Setiap fitoplankton yang berhasil diamati dibawah mikroskop cahaya lalu diidentifikasi sampai tingkat jenis menggunakan buku identifikasi fitoplankton dan diidentifikasi Bellinger dan Sigee (2010), dan Needham dan Needham (1941).

Analisis data :

Indeks Kelimpahan

Keterangan :

$$
\mathrm{N}=\frac{\mathrm{CxV} 1}{\mathrm{~V} 2 \mathrm{XV3}}
$$

$\mathrm{N}=$ jumlah individu fitoplankton per $\mathrm{ml}$

$\mathrm{C}=$ jumlah individu fitoplankton yang dihitung

$\mathrm{V} 1=$ volume contoh uji yang telah disaring $(5000 \mathrm{ml})$

$\mathrm{V} 2=$ volume benda uji $(1 \mathrm{ml})$

$\mathrm{V} 3=$ volume contoh uji yang diambil di lapangan $(100 \mathrm{ml})$

Indeks Keanekaragaman (H')

$$
\mathrm{H}^{\prime}=-\sum P i \ln P i
$$

Keterangan :

$\mathrm{H}^{\prime}=$ indeks diversitas Shanon-Wiener

$\mathrm{Pi}=\mathrm{ni} / \mathrm{N}$ (proporsi jenis fitoplankton)

$\ln =$ jumlah jenis fitoplankton

$\mathrm{N}=$ jumlah seluruh jenis fitoplankton

Indeks Keseragaman (E)

Keterangan :

$$
\mathrm{E}=\frac{\mathrm{H}^{\prime}}{\mathrm{H}^{\prime} \mathrm{maks}}
$$

$\mathrm{E}=$ Indeks keseragaman jenis

$\mathrm{H}^{\prime}=$ Indeks keanekaragaman jenis

Shannon-Wiener

H' maks= Nilai keanekaragaman jenis

maksimum $(\ln S)$

$\mathrm{S}=$ Jumlah total individu

Indeks Dominansi (D)

$$
\mathrm{D}=\sum(P i)^{2}
$$

Keterangan :

$\mathrm{D}=$ Indeks dominasi

$\mathrm{Pi}=\mathrm{ni} / \mathrm{N}$ (proporsi jenis fitoplankton)

Indeks Saprobitas (X)

$$
X=\frac{C+3 D-B-3 A}{A+B+C+D}
$$

Keterangan :

$\mathrm{A}=$ jumlah organisme divisi Cyanophyta

$\mathrm{B}=$ jumlah organisme divisi Euglenophyta

$\mathrm{C}=$ jumlah organisme divisi Chrysophyta

$\mathrm{D}=$ jumlah organisme divisi Chlorophyta

\section{HASIL DAN PEMBAHASAN}

Hasil identifikasi fitoplankton dari sampel air Situ Bulakan Kota Tangerang ditemukan fitoplankton yang berasal dari kingdom Monera (divisi Cyanobacteria) terdiri dari 1 kelas yaitu Cyanophyceae, sedangkan kingdom Protista mirip tumbuhan (mikroalga) terdiri dari 3 kelas yaitu Bacillariophyceae, Chlorophyceae, dan Euglenophyceae. Fitoplankton yang ditemukan diambil dari sampel air 4 stasiun penelitian dan terdiri dari 26 jenis dengan jumlah total 613 individu (Tabel 1). 
Tabel 1. Fitoplankton yang ditemukan di Situ Bulakan Kota Tangerang

\begin{tabular}{|c|c|c|c|c|c|c|}
\hline \multirow{2}{*}{ Kelas } & \multirow{2}{*}{ Jenis } & \multicolumn{4}{|c|}{ Jumlah Individu } & \multirow{2}{*}{ Total } \\
\hline & & ST1 & ST2 & ST3 & ST4 & \\
\hline \multirow{7}{*}{ Cyanophyceae } & Microcystis aeruginosa & 2 & 1 & 0 & 1 & 4 \\
\hline & Aphanocapsa sp. & 0 & 2 & 0 & 0 & 2 \\
\hline & Oscillatoria sp. & 29 & 38 & 36 & 27 & 130 \\
\hline & Lyngbya birgei & 0 & 0 & 17 & 7 & 24 \\
\hline & Scytonema sp. & 1 & 0 & 0 & 0 & 1 \\
\hline & Aphantzomenon flos-aquae & 0 & 2 & 0 & 3 & 5 \\
\hline & Nodularia sp. & 0 & 11 & 0 & 0 & 11 \\
\hline \multirow{4}{*}{ Bacillariophyceae } & Nitzschia acicularis & 8 & 2 & 2 & 4 & 16 \\
\hline & Surirella tenera & 2 & 2 & 0 & 5 & 9 \\
\hline & Gyrosigma sp. & 1 & 0 & 0 & 0 & 1 \\
\hline & Synedra ulna & 1 & 0 & 0 & 0 & 1 \\
\hline \multirow[b]{2}{*}{ Chlorophyceae } & Monoraphidium sp. & 64 & 41 & 56 & 54 & 215 \\
\hline & Pediastrum duplex & 0 & 3 & 1 & 0 & 4 \\
\hline \multirow{8}{*}{ Chlorophyceae } & Coelastrum microporum & 1 & 1 & 0 & 0 & 2 \\
\hline & Scenedesmus sp. & 0 & 0 & 2 & 0 & 2 \\
\hline & Desmodesmus sp. & 1 & 0 & 0 & 0 & 1 \\
\hline & Desmidium grevilli & 0 & 0 & 3 & 0 & 3 \\
\hline & Pleurotaentum trabecula & 3 & 1 & 1 & 1 & 6 \\
\hline & Spirogyrasp. & 1 & 0 & 14 & 2 & 17 \\
\hline & Sphaeroplea sp. & 1 & 0 & 0 & 0 & 1 \\
\hline & Eudorina elegans & 0 & 8 & 3 & 1 & 12 \\
\hline \multirow[t]{2}{*}{ Euglenophyceae } & Euglena viridis & 8 & 13 & 25 & 22 & 68 \\
\hline & E. acus & 3 & 8 & 18 & 11 & 40 \\
\hline \multicolumn{2}{|c|}{ Jumlah Total Individu } & 132 & 141 & 188 & 152 & 613 \\
\hline \multicolumn{2}{|c|}{ Jumlah Total Jenis } & 18 & 15 & 13 & 13 & 26 \\
\hline
\end{tabular}

Tabel 1 menunjukkan jenis fitoplankton yang paling banyak ditemukan di perairan Situ Bulakan Kota Tangerang berasal dari kelas Chlorophyceae yaitu 11 jenis. Monoraphidium sp. merupakan jenis yang ditemukan di Situ Bulakan Kota Tangerang dengan jumlah 215 individu dan merupakan jumlah individu tertinggi (Tabel 1).

Analisis fitoplankton yang dilakukan menggunakan indeks biologi pada 4 stasiun penelitian di Situ Bulakan Kota Tangerang yaitu indeks kelimpahan, indeks keanekaragaman (H'), indeks keseragaman (E), indeks dominansi (D), dan indeks saprobitas $(\mathrm{X})$.

Indeks kelimpahan fitoplankton pada 4 stasiun penelitian bervariasi antara 6.600-9.817 ind/ml, sedangkan kelimpahan rata-rata fitoplankton yaitu 7.992 ind $/ \mathrm{ml}$. Berdasarkan hasil indeks kelimpahan fitoplankton, tingkat kesu-buran perairan Situ Bulakan Kota Tangerang termasuk ke dalam kategori perairan mesotrofik dengan kelimpahan fitoplank- ton antara 2.000-15.000 ind $/ \mathrm{ml}$. Indeks kelimpahan fitoplankton terendah terdapat pada ST1 sebesar $6.600 \mathrm{ind} / \mathrm{ml}$ dan tertinggi terdapat pada ST3 sebesar 9.817 ind/ml (Tabel 2).

Indeks keanekaragaman fitoplankton (H') pada 4 stasiun penelitian bervariasi antara 1,77-2,05, sedangkan keanekaragaman rata-rata fitoplankton yaitu 1,95. Berdasarkan hasil indeks keanekaragaman fitoplankton, diketahui bahwa keanekaragaman fitoplankton di Perairan Situ Bulakan Kota Tangerang termasuk ke dalam kategori sedang dengan nilai $1<\mathrm{H}^{\prime}>3$. Indeks keanekaragaman fitoplankton terendah terdapat pada ST1 sebesar 1,77 dan tertinggi terdapat pada ST2 sebesar 2,05 (Tabel 2).

Indeks keseragaman fitoplankton (E) pada 4 stasiun penelitian bervariasi antara 0,17-0,29, sedangkan keseragaman ratarata fitoplankton yaitu 0,21 (Tabel 2). Berdasarkan hasil tersebut, diketahui bahwa keseragaman fitoplankton di Perairan Situ Bulakan Kota Tangerang 
termasuk ke dalam kategori komunitas tertekan, karena keseragaman populasi pada semua titik sampling memiliki nilai mendekati 0 .

Indeks dominansi fitoplankton (D) pada 4 stasiun penelitian bervariasi antara 0,61-0,79, sedangkan dominansi rata-rata fitoplankton yaitu 0,73 . Indeks dominansi terendah yaitu pada ST 1 sebesar 0,61 dan termasuk ke dalam kategori dominansi sedang, sedangkan indeks dominansi tertinggi pada ST3 sebesar 0,79 dan termasuk ke dalam kategori dominansi tinggi (Tabel 2). Terlihat pada tabel 1, seluruh stasiun penelitian memiliki jenis yang lebih mendominasi seperti Monoraphidium sp. dan Oscillatoria sp.

Indeks saprobitas fitoplankton (X) pada 4 stasiun penelitian bervariasi antara 0,03-0,80 dengan kategori $\alpha$-mesosaprobik sampai $\beta$-mesosaprobik, sedangkan indeks saprobitas rata-rata fitoplankton yaitu 0,14. Nilai indeks saprobitas terendah yaitu pada ST4 sebesar -0,03 yang menunjukkan kualitas air mengalami pencemaran sedang sampai berat atau $\alpha-$ mesosaprobik dan nilai indeks saprobitas tertinggi yaitu pada ST1 sebesar 0,80 yang menunjukkan kualitas air mengalami pencemaran sedang sampai berat atau $\beta$ mesosaprobik (Tabel 2).

Tabel 2. Indeks Biologi Fitoplankton di Situ Bulakan Kota Tangerang

\begin{tabular}{|c|c|c|c|c|c|}
\hline $\begin{array}{c}\text { Stasiun } \\
\text { Penelitian }\end{array}$ & $\begin{array}{c}\text { Indeks } \\
\text { Kelimpahan }\end{array}$ & $\begin{array}{c}\text { Indeks } \\
\text { Keanekaragaman } \\
\left(\mathrm{H}^{\prime}\right)\end{array}$ & $\begin{array}{c}\text { Indeks } \\
\text { Keseragaman } \\
(\mathrm{E})\end{array}$ & $\begin{array}{c}\text { Indeks } \\
\text { Dominansi } \\
(\mathrm{D})\end{array}$ & $\begin{array}{c}\text { Indeks } \\
\text { Sprobitas } \\
(\mathrm{X})\end{array}$ \\
\hline ST1 & 6.600 & 1,77 & 0,29 & 0,61 & 0,80 \\
\hline ST2 & 7.950 & 2,05 & 0,18 & 0,76 & $-0,29$ \\
\hline ST3 & 9.817 & 2,02 & 0,17 & 0,79 & 0,05 \\
\hline ST4 & 7.600 & 1,95 & 0,20 & 0,76 & $-0,03$ \\
\hline Rata-rata & 7.992 & 1,95 & 0,21 & 0,73 & 0.14 \\
\hline
\end{tabular}

Tabel 3. Hasil Pengukuran Parameter Fisik dan Kimia Situ Bulakan Kota Tangerang

\begin{tabular}{|c|c|c|c|c|}
\hline Parameter & ST1 & ST2 & ST3 & ST4 \\
\hline Suhu & 29,2 & 29,35 & 29,3 & 28,6 \\
\hline Kecerahan $(\mathrm{cm})$ & 9,5 & 11,5 & 26 & 39 \\
\hline Kedalaman $(\mathrm{m})$ & 0,9 & 0,55 & 0,8 & 0,6 \\
\hline Salinitas & 0,2 & 0,2 & 0,2 & 0,2 \\
\hline TSS & 30 & 28 & 33,5 & 16 \\
\hline $\mathrm{pH}$ & 7,515 & 6,99 & 7,37 & 7,37 \\
\hline DO & 1,17 & 2,82 & 2,385 & 2,87 \\
\hline Amoniak & 2,36 & 2,065 & 2,87 & 3,03 \\
\hline
\end{tabular}

Pengukuran fisik dan kimia perairan yang dilakukan pada 4 stasiun penelitian di Situ Bulakan Kota Tangerang yaitu suhu, kecerahan, kedalaman, salinitas, TSS, derajat keasaman $(\mathrm{pH})$, kandungan oksigen terlarut (DO), dan amoniak $\left(\mathrm{NH}_{3}-\mathrm{N}\right)$ (Tabel 3).

Berdasarkan tabel 3, hasil pengukuran suhu perairan diperoleh nilai antara
28,60-29,35 ${ }^{\circ} \mathrm{C}$. Pengukuran kecerahan diperoleh nilai antara $0,10-0,40 \mathrm{~m}$. Kecerahan terendah yaitu pada ST1 sebesar $0,10 \mathrm{~m}$ dan tertinggi pada ST4 sebesar 0,40 m (Tabel 3). Pengukuran kedalaman perairan diperoleh nilai antara 0,5-0,9 m (Tabel 3).

Pengukuran salinitas menunjukkan nilai yang sama pada setiap stasiun 
penelitian yaitu $0,2 \%$ atau dapat dikonversi menjadi $0,02 \%$ (Tabel 3). Pengukuran TSS perairan diperoleh nilai antara 16,00-33,50 $\mathrm{mg} / \mathrm{L}$. Nilai TSS terendah yaitu pada ST4 sebesar 16,00 $\mathrm{mg} / \mathrm{L}$ dan tertinggi pada ST3 sebesar 33,50 $\mathrm{mg} / \mathrm{L}$ (Tabel 3). Pengukuran derajat keasaman $(\mathrm{pH})$ perairan diperoleh nilai antara 6,99-7,51 (Tabel 3). Pengukuran kandungan oksigen terlarut (DO) perairan diperoleh nilai antara 1,17-2,87 $\mathrm{mg} / \mathrm{L}$ (Tabel 3). Pengukuran amoniak perairan diperoleh nilai antara 2,06-3,03 $\mathrm{mg} / \mathrm{L}$ (Tabel 3).

Chlorophyceae merupakan fitoplankton yang paling banyak ditemukan di perairan Situ Bulakan Kota Tangerang dan satu-satunya kelas yang terdapat pada divisi Chlorophyta. Jumlah spesies dari kelas Chlorophyceae paling beragam dibandingkan dengan kelas yang lain dengan jumlah mencapai 17.000 spesies (Graham \& Wilcox, 2000). Chlorophyceae umumnya banyak ditemukan di perairan air tawar karena sifatnya mudah beradaptasi dan cepat berkembang biak sehingga populasinya banyak ditemukan di perairan. Fitoplankton dari kelas Chlorophyceae umumnya melimpah di perairan dengan intensitas cahaya yang cukup seperti kolam, situ, dan danau (Bellinger \& Sigee, 2010).

Monoraphidium sp. merupakan jenis fitoplankton yang paling banyak ditemukan di perairan Situ Bulakan dan salah satu fitoplankton yang digunakan sebagai indikator perairan yang tercemar. Jenis ini memiliki protective cyste yang merupakan fase dari organisme uniseluler yang dilindungi oleh lapisan tebal sehingga dapat bertahan hidup lebih lama pada kondisi yang tidak menguntungkan tanpa mengambil makanan (Jhon et al., 2002). Monoraphidium sp. banyak ditemukan di Situ Bungur Kota Tangerang Selatan (339 individu) (Salam, 2010), Situ Babakan Jakarta Selatan (13.258 individu), Situ Ulin-Salam Depok (4.419 individu), dan Situ Aghatis Depok - Kampus Universitas Indonesia (20.328 individu (Prihantini et al., 2008). Fitoplankton berpotensi menjadi indikator terbaik dalam pencemaran organik karena mudah dicuplik dan diidentifikasi sehingga dapat menjadi indikator pencemaran yang baik di suatu perairan.

Kelimpahan fitoplankton berkaitan dengan tingkat kesuburan suatu perairan. Kelimpahan fitoplankton ini dipengaruhi oleh faktor abiotik seperti DO atau kandungan oksigen terlarut (Tabel 3). Kandungan DO di perairan yang dapat ditolerir oleh organisme akuatik terutama fitoplankton adalah tidak kurang dari 5 mg/L (Boyd, 1982). Menurut PP No. 82 Tahun 2001, batas minimal kandungan DO untuk kategori kelas III (perikanan) yaitu 4 mg/L. Kandungan DO perairan Situ Bulakan Kota Tangerang berada dibawah nilai ambang batas yang ditetapkan, sehingga perairan tidak terlalu mendukung untuk kegiatan perikanan dan mempengaruhi kelimpahan fitoplankton di dalamnya. Kandungan DO perairan berkaitan dengan suhu (Manik, 2010). Pengukuran DO di 4 stasiun penelitian tidak memiliki perbedaan yang signifikan karena suhu perairan pada masing-masing stasiun penelitian juga tidak memiliki perbedaan yang signifikan (Tabel 3).

Suhu perairan di 4 stasiun penelitian tidak memiliki perbedaan secara signifikan. Hal ini disebabkan karena pengukuran suhu perairan dilakukan dalam waktu yang hampir bersamaan yaitu pada pukul 09.00 WIB. Suhu berpengaruh terhadap distribusi fitoplankton. Kisaran suhu optimum bagi kehidupan fitoplankton di perairan adalah $20-30^{\circ} \mathrm{C}$ (Rimper, 2001). Nilai kisaran suhu pada perairan Situ Bulakan menunjukkan kisaran suhu yang baik untuk pertumbuhan fitoplankton.

Indeks keanekaragaman terendah terjadi pada ST1 yang merupakan tempat aliran air masuk (inlet). Hal ini disebabkan karena ST1 banyak tertutupi oleh adanya sampah yang menggenang di permukaan perairan. Limbah rumah tangga yang masuk melalui inlet Situ Bulakan Kota Tangerang seperti plastik, dedaunan, sabun 
atau busa detergen sebagai salah satu faktor yang menyebabkan terhambatnya sinar matahari masuk ke perairan, sehingga proses fotosintesis yang dilakukan oleh fitoplankton menjadi berkurang dan menyebabkan rendahnya keanekaragaman jenis fitoplankton pada stasiun ini. Proses fotosintesis yang terhambat pada perairan juga menyebabkan ragam dan jenis tertentu saja yang hidup pada stasiun ini.

Indeks keanekaragaman tertinggi terjadi pada ST2 merupakan bagian tengah danau yang langsung mendapatkan cahaya matahari, sehingga dapat meningkatkan produktivitas primer perairan. Cahaya merupakan faktor penting karena berdampak langsung terhadap distribusi dan jumlah organisme khususnya fitoplankton dalam badan air (Anggoro et al., 2013).

Indeks keseragaman (E) menggambarkan tingkat keseimbangan atau kesamaan komposisi jenis biota perairan (Odum, 1996). Rendahnya nilai indeks keseragaman pada seluruh stasiun penelitian disebabkan karena kelimpahan fitoplankton yang tidak merata, sehingga adanya spesies yang lebih mendominasi dalam perairan. Semakin kecil nilai indeks keseragaman atau mendekati nol menunjukkan semakin kecil pula keseragaman populasi fitoplankton, artinya penyebaran jumlah individu setiap spesies tidak sama dan cenderung suatu spesies tertentu mendominasi populasi tersebut (Nugroho, 2006).

Indeks dominansi fitoplankton (D) menggambarkan ada atau tidaknya biota perairan yang mendominasi (Odum, 1996). Jika indeks dominansi mendekati nilai 1 maka ada salah satu jenis yang mendominasi daripada jenis lain, hal ini disebabkan karena komunitas fitoplankton mengalami tekanan ekologis berupa stress (Nugroho, 2006).

Indeks saprobitas fitoplankton (X) terendah terjadi pada ST4 yang berarti terjadi pencemaran yang disebabkan karena adanya kegiatan budidaya perikanan menggunakan sistem keramba jaring apung (KJA). Kegiatan budidaya keramba jaring apung mengandung bahan organik dari penggunaan pakan buatan yang tidak termakan dan akan menumpuk pada dasar perairan (Hutabarat, 2000). Limbah organik KJA tersusun atas bahan organik seperti karbon, hidrogen, oksigen, nitrogen, fosfor, sulfur dan mineral lainnya. Limbah organik yang masuk ke dalam perairan dalam bentuk padatan yang terendap, koloid, tersuspensi dan terlarut mempunyai potensi yang besar untuk menurunkan kualitas air (Panjaitan, 2009).

ST1 memiliki indeks saprobitas fitoplankton (X) tertinggi karena merupakan tempat aliran masuk (inlet) yang mengandung limbah organik dan anorganik dari hasil aktivitas pabrik dan rumah tangga di sekitar perairan Situ Bulakan Kota Tangerang. Limbah organik secara tidak langsung dapat meningkatkan kelimpahan jenis fitoplankton tertentu. Kondisi perairan yang cukup mengandung unsur hara diperlukan untuk perkembangan fitoplankton seperti nitrat dan fosfat yang berasal dari buangan limbah rumah tangga dan industri (Piirsoo et al., 2008).

Terhambatnya penetrasi cahaya matahari ke dalam air menyebabkan proses fotosintesis dalam air akan terganggu dan jumlah oksigen terlarut dalam air akan berkurang. Penurunan jumlah kandungan oksigen terlarut dalam air menyebabkan terganggunya kehidupan organisme perairan terutama bagi pertumbuhan fitoplankton (Manik, 2010).

Jenis fitoplankton yang dapat mendominasi suatu perairan dapat dipe-ngaruhi oleh kondisi lingkungan seperti faktor fisik dan kimia perairan seperti kecerahan, kedalaman, salinitas, $\mathrm{pH}$, TSS, dan amoniak $\left(\mathrm{NH}_{3}-\mathrm{N}\right)$ yang mampu memberikan perbedaan jenis fitoplankton yang mendominasi pada setiap perairan (Reynold, 1993).

Perairan yang memiliki kecerahan 0,60 m-0,90 m dianggap cukup baik untuk menunjang kehidupan ikan dan organisme perairan dan kecerahan $<0,30 \mathrm{~m}$ dapat menimbulkan masalah bagi ketersediaan 
oksigen terlarut di perairan (Boyd, 1982). Hasil pengukuran kecerahan di Situ Bulakan Kota Tangerang <0,30 m sehingga kurang mendukung bagi kehidupan dan pertumbuhan organisme perairan terutama fitoplankton.

Kedalaman perairan di 4 stasiun penelitian tidak memiliki perbedaan secara signifikan. Hal ini terjadi karena pengerukan dasar perairan situ tidak dilakukan secara menyeluruh, sehingga bahan-bahan organik dan anorganik yang mengendap di dasar perairan terus terakumulasi dan menyebabkan pendangkalan pada bagian dasar. Perairan yang baik untuk pemeliharaan ikan berkisar antara 0,751,25 m, karena air pada kedalaman tersebut masih dipengaruhi oleh sinar matahari sehingga merupakan lapisan yang produktif.

Kedalaman perairan juga merupakan faktor pembatas kesuburan perairan. Fitoplankton banyak dijumpai pada kedalaman tidak lebih dari satu meter pada perairan umum (sungai, danau, dan waduk) karena pada kedalaman satu meter merupakan daerah transparansi matahari (euphotic zone) (Harahap, 2000). Berdasarkan pendapat tersebut, kedalaman perairan Situ Bulakan masih layak sebagai tempat kehidupan organisme perairan seperti ikan yang banyak hidup pada tambak-tambak disekitar Situ Bulakan dan fitoplankton yang cukup banyak ditemukan di Situ Bulakan Kota Tangerang.

Salinitas yang terkandung pada air danau dan sungai terhitung rendah dan dikategorikan sebagai air tawar jika kandungan garam pada air sungai dan danau kurang dari $0,05 \%$. Jika melebihi itu atau sekitar 0,05\% sampai 3\% maka air tersebut dikategorikan sebagai air payau. Jika tingkat salinitasnya diantara 3\% sampai $5 \%$ air tersebut dikategorikan sebagai air saline dan jika melebihi 5\% maka dikategorikan sebagai brine (KLH Ketapang, 2013). Hal ini menunjukkan bahwa hasil pengukuran salinitas pada setiap stasiun penelitian termasuk kategori air tawar.
Nilai TSS terendah pada ST4 terjadi karena nilai kecerahan pada ST4 lebih tinggi dibandingkan stasiun penelitian yang lain, sementara nilai TSS tertinggi pada ST3 terjadi karena nilai kecerahan pada ST3 lebih rendah dibandingkan dengan nilai kecerahan pada ST4 (Tabel 3). Menurut PP No. 82 tahun 2001 mengenai baku mutu air kelas III (untuk perikanan) bahwa TSS memiliki nilai ambang batas maksimal $400 \mathrm{mg} / \mathrm{L}$, dalam hal ini TSS perairan Situ Bulakan Kota Tangerang tergolong normal karena nilai TSS berada dibawah nilai ambang batas.

Kisaran pH yang sesuai untuk kehidupan organisme perairan adalah 6,5-9 (Boyd, 1982). Nilai pH yang terdapat pada masing-masing stasiun tidak memperlihat perbedaan yang signifikan dan berada dalam kondisi normal. Menurut PP No. 82 tahun 2001, dalam kriteria baku mutu air kelas III (untuk perikanan) adalah 6-9. Dengan demikian, nilai $\mathrm{pH}$ yang terdapat pada setiap stasiun penelitian dapat disimpulkan bahwa perairan tersebut tergolong kepada perairan yang produktif untuk kehidupan organisme fitoplankton dan berada dibawah ambang batas yang ditetapkan.

Hasil pengukuran amoniak di setiap stasiun penelitian tidak memperlihat perbedaan yang signifikan. Baku mutu kualitas air kelas III (untuk perikanan) dalam PP No. 82 Tahun 2001 menjelaskan bahwa batas maksimum amoniak untuk kegiatan perikanan bagi ikan yang peka $\leq 0,02 \mathrm{mg} / \mathrm{L}$. Hal ini menunjukkan bahwa kandungan amoniak pada setiap stasiun penelitian telah melewati batas maksimum baku mutu.

Kandungan amoniak yang tinggi pada setiap stasiun, diduga disebabkan oleh adanya akumulasi dari pemberian pakan dengan teknik sebar pada areal budidaya ikan di lokasi tersebut sehingga menyebabkan sisa-sisa buangan hasil metabolisme yang dihasilkan oleh ikan dalam bentuk feces menjadi lebih banyak, dan mempengaruhi tingginya jumlah kadar amoniak di lokasi tersebut. Selain itu, 
pembuangan limbah rumah tangga yang masuk melalui inlet juga merupakan faktor yang menyebabkan kandungan amoniak menjadi tinggi.

\section{KESIMPULAN}

Berdasarkan hasil penelitian, didapatkan kesimpulan bahwa keanekaragaman fitoplankton yang ditemukan sebanyak 26 jenis yang termasuk ke dalam 4 kelas yaitu Cyanophyceae (9 jenis), Bacillariophyceae (4 jenis), Chlorophyceae (11 jenis), dan Euglenophyceae (2 jenis) dengan indeks keanekaragaman sedang $\left(H^{\prime}=1,77-2,05\right)$ dan Kondisi saprobitas perairan di Situ Bulakan Kota Tangerang berdasarkan indikator fitoplankton yaitu tercemar sedang sampai berat $(\alpha-$ mesosaprobik) dengan nilai rata-rata indeks 0,14 .

\section{UCAPAN TERIMA KASIH}

Terima kasih kepada Pusat Sarana Pengendalian Dampak Lingkungan (Pusarpedal)-Kementerian Lingkungan Hidup dan Kehutanan RI yang telah memfasilitasi penelitian serta Kantor Kesatuan Bangsa dan Perlindungan Masyarakat (Kesbanglinmas) Kota Tangerang yang telah memberikan perizinan penelitian dan pengambilan sampel di Situ Bulakan Kota Tangerang.

\section{DAFTAR PUSTAKA}

Anggoro, S., P. Soedarsono, dan Suprobo. H.D. (2013). Penilaian Pencemaran Perairan di Polder Tawang Semarang ditinjua dari Aspek Saprobitas. Journal of Management of Aquatic Resources 2 (3), 109-118.

Arinardi, O.H., Sutomo, A.B., Yusuf S.A., Trimaningsih, Asnaryanti, E. \& Riyono, S.H. (1997). Kisaran Kelimpahan dan Komposisi Plankton Predominan di Perairan Kawasan Timur Indonesia. Pusat Penelitian dan Pengembangan Oseanologi Lembaga Ilmu Pengetahuan Indonesia. Jakarta.
Badan Standarisasi Nasional (BSN). (2004). Kumpulan SNI (Standar Nasional Indonesia) untuk Air dan Air Limbah. Badan Standarisasi Nasional. Jakarta.

Bellinger, E. G., \& Sigee, D.C. (2010). Freshwater Algae: Identification and Use as Bioindicators. John Wiley \& Sons Ltd. United Kingdom.

BPLH Kota Tangerang. (2013). Laporan Status Lingkungan Hidup Daerah (SLHD) Kota Tangerang Tahun 2013. Pemerintah Kota Tangerang. Tangerang.

Boyd, C. E. (1982). Water Quality Management for Pond Fish Culture. Elsevier Scientific Publishing Company Amsterdam New York.

Graham, L. E. \& Wilcox, L. W. (2000). Algae. Prentice Hall Inc. New Jersey.

Harahap. (2000). Analisis Kualitas Air Sungai Kampar dan Identifikasi Bakteri Patogen di Desa Pongkai dan Batu Besurat Kecamatan kampar kabupaten Kampar. Pusat Penelitian Universitas Riau. Pekanbaru.

Hutabarat, S. (2000). Produktivitas Perairan dan Plankton. Badan Universitas Diponegoro. Semarang.

Indrayani, N., Anggoro, S., \& Suryanto, A. (2014). Indeks Trofik-Saprobik Sebagai Indikator Kualitas Air di Bendung Kembang Kempis Wedung, Kabupaten Demak. Diponegoro Journal of Maquares Management of Aquatic Resources 3 (4), 161-168.

Jhon, D. M., Whitton, B. A., \& Brook, A. J. (2002). The Freshwater Algal Floral of the British Isles. United Kingdom: Cambridge University Press.

Kantor Lingkungan Hidup (KLH) Ketapang. (2013). Laporan Pemantauan Kualitas Air Sungai tahun 2013 Kabupaten Ketapang. Kantor Lingkungan Hidup Kabupaten Keta-pang. Ketapang. 
Manik, D. M. (2010). Studi Tentang Kenaikan Amoniak $\left(\mathrm{NH}_{3}\right)$ Dan Sulfat $\left(\mathrm{SO}_{4}{ }^{-2}\right)$ Pada Air Limpasan Pengerukan Pasir Laut serta Pengaruhnya terhadap Kelimpahan Popu-lasi Plankton dan Bentos. Skripsi. Departemen Kimia Fakultas Matematika dan Ilmu Pengetahuan Alam Universitas Sumatera Utara. Medan.

Needham, J. G., \& Needham, P. R. (1941). A Guide to the Study of Fresh-Water Biology. Comstock Publishing Company Inc. New York.

Nugroho, A. (2006). Bioindikator Kualitas Air. Universitas Trisakti. Jakarta.

Nybakken, J. W. (1992). Biologi Laut. Gramedia Pustaka Utama. Jakarta.

Odum, E. P. (1996). Dasar-dasar Ekologi. Yogyakarta: Gadjah Mada University Press.

Panjaitan, P. (2009). Kajian Potensi Pencemaran Keramba Jaring Apung PT. Aquafarm Nusantara di Ekosis-tem Perairan Danau Toba. Jurnal Visi 17 (3), 290-300.
Piirsoo, K., Peeter, P., Tuvikene, A., \& Malle, A. (2008). Temporal and Spatial Patterns of Phytoplankton in a Temperate Lowland River. Journal of Plankton Research 30 (11), 1.2851.295.

Presiden Republik Indonesia. (2001). Pera-turan Pemerintah Republik Indone-sia Nomor 82 Tahun 2001 tentang Pengelolaan Kualitas Air dan Pe-ngendalian Pencemaran Air. Sekretaris Negara Republik Indonesia. Jakarta.

Prihantini, N. B., Wardhana, W. Hendrayanti, D., Widyawan, A., Ariyani, Y., \& Rianto, R. (2008). Biodiversitas Cyanobacteria dari Beberapa Situ/ Danau di Kawasan Jakarta-Depok-Bogor, Indonesia. Jurnal Makara Sains 12 (1), 44-54.

Reynold, C. S. (1993). Scales of Disturbance and Tehir Role in Plankton Ecology. Hydrobiology (249), 157-171. 